\title{
Quem é você, Ana? ${ }^{1}$
}

\section{Eliana da Silveira Cruz Caligiuri ${ }^{2}$}

Foi a mãe quem, numa rara atitude de rebeldia em relação às regras familiares ditadas pelo pai, procurou ajuda para Ana , que deixara de frequentar a escola, as festas e as reuniões de amigos havia um ano e meio, desde seus 15 anos.

A garota vivia em permanente conflito com o seu corpo, alternando episódios de compulsão alimentar e bulimia.

A mãe não compreendia como a filha tinha chegado a esse estado de ansiedade e distorção da realidade, já que era linda e sempre fora considerada uma das garotas mais bonitas da escola.

Ainda havia outro agravante : o relacionamento familiar estava deteriorado pelas constantes brigas entre o pai e Ana, algo incompreensível para a mãe, pois eles sempre foram muito próximos e íntimos. Desde muito pequena Ana era a garotinha linda e inteligente, a preferida do pai em relação aos dois irmãos mais novos.

Duas cenas dramáticas provocaram a ruptura do campo de dominação-submissão da mãe em relação ao marido:

1- Encontrou Ana com o olhar perdido, sentada sobre uma pilha de roupas que havia jogado no chão do quarto. A garota parecia em transe, sem responder aos apelos da mãe.

2- Ao saber que a filha estava no banho por mais de uma hora, o pai , num acesso de fúria, arrombou a porta arrastando Ana do banheiro e dando-lhe uma surra.

\footnotetext{
${ }^{1}$ Este trabalho foi apresentado na mesa "XXXX” com Eugenio Canesin Dal Molin no I Simpósio Bienal "O mesmo, o outro: Psicanálise em movimento" da Sociedade Brasileira de Psicanálise de São Paulo.

2 Membroo associado da Sociedade Brasileira
} 
A "cortina de fumaça-bulimia" erguia-se e os bastidores da relação pai e filha mostravam seus sinais.

Na entrevista com os pais, o pai, sem esconder o inconformismo e o autoritarismo, contou que educava e orientava os filhos conversando sobre todos os assuntos: politica, estudo, religião, profissão, sexo... A imagem de "a maioral" - linda, madura e resolvida -, cultivada pela dupla filha-pai, sofrera um abalo e ele não aceitava o fato.

Foi urgente apontar o sofrimento da garota, mostrar sua séria situação psíquica e a necessidade de acolher Ana e tentar compreender o que estava ocorrendo. Assim, foi possível ganhar terreno para uma trégua familiar com o objetivo de iniciar o trabalho psicanalítico .

\section{Ana e seus irmãos}

O relacionamento da garota com os irmãos também estava conturbado. A reação deles aos conflitos familiares era bastante oposta:

Ricardo, um ano e meio mais novo, era carinhoso e tentava ajudá-la, emprestando seus moletons, as únicas roupas que Ana usava, após se recusar a vestir as suas próprias roupas.

Com André, 3 anos mais novo, a situação era outra: impaciente e irritado, agredia constantemente a irmã, chamando-a de louca.

Ana

"Este é um salão de feiura, não um salão de beleza,

Ruth disse." (p33)

\section{Clement}


No belíssimo livro Reze pelas mulheres roubadas, a poeta e romancista mexicana Clement (2014), após 10 anos de entrevistas com mulheres mexicanas, narra a vida das meninas da cidade de Guerreiro que são criadas como meninos por suas mães com o intuito de protegê-las e impedir que sejam sequestradas pelos narcotraficantes. Quando os primeiros sinais da puberdade despontam nos corpos das garotas, suas mães cavam buracos no quintal das casas para esconder as filhas.

Ao conhecer Ana pude observar uma linda menina que tentava esconder sua beleza cobrindo-a com moletons folgados, e nada femininos, de seu irmão Ricardo. Que corpo ela escondia debaixo daqueles panos? De quem ela escondia com a queixa de que estava tão gorda e feia que ninguém poderia vê-la?

Mas não havia sido sempre assim. Dos 13 aos 15 anos expunha o corpo usando roupas justas, curtas e decotadas - aquelas que ela jogara ao chão. Desfilava para seu pai antes de sair para as festas, ele ajudava a escolher as roupas e aprovava com admiração.

Na cidade de Guerreiro, as mães cavavam buracos para esconder e proteger suas filhas, nesse caso foi Ana quem cavou o próprio "buraco": o quarto onde passou a viver seus dias, só aceitando sair para vir ao consultório.

Em inúmeras sessões "vomitou", ansiosamente, queixas e teorias a seu respeito e a respeito da vida, algumas aprendidas com o pai , outras em programas de TV que "engolia" compulsivamente. Parar para pensar era angustiante. Não havia livros, filmes ou músicas ampliando seu dia a dia. Era Ana e sua mãe, sendo que esta se limitava a dizer à filha que o que ela pensava era bobagem e a cozinhar as inúmeras receitas para cumprir com as infindáveis dietas. 
Não havia uma mãe - como a da personagem Ladydi Garcia Martinez do livro citado - que assistisse a documentários históricos e usasse metáforas sobre Troia, Império Romano, entre outras, para sustentar emocionalmente a filha e colorir seu cotidiano.

\section{Travessia}

“Quando voltei ao salão de beleza, todo mundo já havia tirado o esmalte das unhas. Era óbvio que ninguém ia se arriscar a sair para um mundo em que os homens acham que podem roubar você só porque suas unhas estão pintadas de vermelho." (p 34)

Clement

Durante a inquietante travessia, algumas peças do quebra - cabeça foram surgindo e a primeira delas - sua única relação sexual aos 15 anos - foi a ponta do iceberg. Embora tenha sido com um rapaz conhecido, pouco mais velho do que ela, Ana foi assaltada pelo medo e culpa, pois esquecera de usar camisinha.

De início o pavor foi da gravidez, depois a paranoia das doenças. Após os exames com resultados negativos surgiu, por fim, a vergonha de seu corpo. Além da mudança radical quanto à escola , às roupas e a repetição do mantra "estou gorda", surgiram os episódios bulímicos e a rápida degradação da relação com o pai. Recusava-se a conversar com ele, rejeitando-o. A reação do pai foi violenta.

A figura paterna autoritária, impositiva e invasiva foi tomando forma e surgiram lembranças de situações conflitivas de um tempo anterior : durante a puberdade, com o corpo transformando-se rapidamente, Ana, em uma das primeiras manifestações de sua subjetividade, passou a trancar a porta de seu quarto. O pai, habituado a ter livre acesso ao quarto da filha, não aceitou a atitude e, após sucessivas brigas, arrombou a porta e tirou a maçaneta impedindo a garota de defender sua 
privacidade. Ressentida, Ana pediu ajuda à mãe que não esboçou qualquer reação em favor da filha. Desamparada, ela inicialmente desistiu, mas quando a crise eclodiu, entrou num embate com o pai, arrastando sua cama para bloquear a entrada do quarto.

\section{O sofrimento de Ana}

Durante o relato me vi diante de uma garota oscilando entre sentimentos de estranhamento, malestar raivoso em relação aos comportamentos do pai e momentos de indiferença, parecendo não estar implicada afetivamente com as atitudes excessivas.

À medida que a confiança de Ana no trabalho terapêutico se constituía, o conteúdo das sessões foi-se modificando, surgindo questionamentos sobre a dinâmica familiar, especialmente a submissão da mãe e a soberania paterna . E os pesadelos foram surgindo, sendo um deles bastante significativo e perturbador: ela está sendo perseguida pelo pai que invadira o quarto e , acuada, vê a janela aberta e corre nesta direção. Acordou sobressaltada e com muito medo. Apontei para Ana que ela me contara antes sobre a falta de privacidade e a invasão de seu quarto , mas que este sonho trazia um desespero sem saída. Ela se emocionou e chorou pela primeira vez na análise, manifestando desalento e desamparo.

Atravessamos um período de tristeza que se intensificava a cada lembrança que emergia, quando o despotismo de seu pai se apresentava com tintas carregadas. Um pai que desfilava sua nudez ao chegar do trabalho. Esse era um hábito que ele tinha desde solteiro e, depois de casar-se e de constituir família, não só o manteve como fazia as refeições com os filhos dessa forma. Percebi o excesso na exposição do corpo do pai e o campo minado que iríamos atravessar. Procurei, com cautela, apontar o que ela estava narrando e levantar mais um véu que encobria os sintomas de Ana. E surgiu uma lembrança: ela, menininha, sentada na cama de casal, fazendo companhia a seu pai nu enquanto a mãe se ocupava dos irmãos menores e do jantar.

Em sessões posteriores lembrou o momento em que começou a estranhar e a se incomodar com a nudez paterna : foi ao frequentar a casa das amigas e conhecer seus pais, vestidos. Pediu a ele para 
não tirar mais as roupas , não foi atendida, nem apoiada por sua mãe. Entendeu então por que não convidava suas amigas para vir à sua casa.

O sentimento de desmoronamento e impotência, que para ela parecia um sinal de incompetência, burrice e falhas emocionais, ganhou outros sentidos, incluindo a dominação tirânica paterna e a exposição excessiva do pai em um comportamento exibicionista e erotizado.

Momento doloroso na análise: o despertar de uma alma confusa e atormentada, aprisionada no próprio corpo e no corpo do pai, conscientizando-se que, no início da puberdade, quando tentou esconder e proteger seu corpo em transformação, foi invadida pelo voyerismo e a possessividade de seu pai.

No livro de Clement, Paula, uma das personagens, é sequestrada pelos narcotraficantes no início da puberdade. Sua mãe tinha vários cachorros como soldados, que latiam quando as SUVs dos violentos homens se aproximavam. No dia do rapto, os cães foram mortos e a mãe não conseguiu esconder sua filha no buraco. Quando Paula retornou para casa seu corpo estava marcado com queimaduras de cigarro, num desenho típico que simbolizava quem era o seu dono.

\section{Quem é você, Ana?}

E Ana, durante o curso da análise, se apresentou : uma garota que foi submetida a duas condições perturbadoras desde a infância.

De um lado, o adulto - pai, erotizado, exibicionista e violento, que sequestrou a infância da filha e deixou uma marca com seu próprio corpo. Com essa postura carregada de estímulos visuais e verbais, ele provocou "um enxerto prematuro", como descreveu Ferenczi (1933), no texto Confusão de línguas entre os adultos e as crianças. É o enxerto de uma forma de amor carregada de paixão e posteriormente de culpa, acompanhada por ódio, este sentimento tem tal intensidade que surpreende e choca a criança, perturbando sua espontaneidade frente à vida. 
Esse ódio em Ana manifestou-se num pesadelo trágico: novamente surge a cena da invasão de seu quarto e , desta vez, ela pega um revólver e atira, matando o próprio pai.

Por outro lado, a garota sofreu também a privação de um importante cuidado materno - "escudo protetor"- , uma das funções apontadas por Freud no texto Além do princípio do prazer (1920), e destacada por Winnicott como sendo tão fundamental quanto holding e o manejo.

Se no livro de Clement, as mães das garotas da cidade mexicana de Guerreiro enfeiam suas filhas, pintam seus dentes com carvão, cavam buracos para escondê-las dos narcotraficantes, a mãe de Ana ofereceu-a ao pai violento, deitado nu em uma cama .

\section{Referências}

Clement, J. - Reze pelas mulheres roubadas / Jennifer Clement; tradução de Léa Viveiros de Castro. $-1^{\mathrm{a}}$ ed - Rio de Janeiro: Rocco 2015

Ferenczi, S. (2011) - Confusão de língua entre os adultos e as crianças (A linguagem da ternura e da paixão) In Obras Completas: Psicanálise IV. São Paulo: Martins Fontes (Original publicado em 1933 [1932])

Freud, S. - ( 1993) Estudios sobre la histeria ( Breuer y Freud) (1893-95) - traduccion directa del aléman: Jose Luis Echeverry. Vol.II. Obras completas. Buenos Aires: Amorrortu Editores 1978-93.

Freud, S. - (1993) Más ala del principio del placer (1920) - traduccion directa del aléman: Jose Luis Echeverry. Vol.XVIII. Obras completas. Buenos Aires: Amorrortu Editores 1978-93. Pp 7-62

Freud, S. - (1993) Esquema del psicoanalisis (1940 [1938]) - traduccion directa del aléman: Jose Luis Echeverry. Vol.XXIII. Obras completas. Buenos Aires: Amorrortu Editores 1978-93. 